\begin{tabular}{|c|l|}
\hline Title & Chemical equilibrium analysis for hydrolysis of magnesium hydride to generate hydrogen \\
\hline Author(s) & Hiraki, Takehito; Hiroi, Shun; A kashi, Takuya; Okinaka, Noriyuki; A kiy ama, Tomohiro \\
\hline Citation & $\begin{array}{l}\text { International Journal of Hydrogen Energy, 37(17), 12114.12119 } \\
\text { https://doi.org/10.1016/.ijhydene.2012.06.012 }\end{array}$ \\
\hline Issue Date & 2012-09 \\
\hline Doc URL & http://hdl.handle.net/2115/50397 \\
\hline Type & article (author version) \\
\hline File Information & IJHE37-17_12114.12119.pdf \\
\hline
\end{tabular}

Instructions for use 


\section{Chemical equilibrium analysis for hydrolysis of magnesium hydride to generate hydrogen}

Takehito Hiraki ${ }^{\mathrm{a}}$, Shun Hiroi ${ }^{\mathrm{b}}$, Takuya Akashi $^{\mathrm{b}}$, Noriyuki Okinaka ${ }^{\mathrm{b}}$ and Tomohiro

Akiyama $^{\mathrm{b}, *}$

${ }^{\mathrm{a}}$ Graduate School of Environmental Studies, Tohoku University, 6-6-11-1004, Aza-Aoba

Aramaki, Aoba-ku, Sendai 980-8579, Japan

${ }^{\mathrm{b}}$ Center for Advanced Research of Energy and Materials, Faculty of Engineering,

Hokkaido University, Sapporo 060-8628, Japan

*Corresponding author: Phone: +81-11-706-6842, Fax: +81-11-726-0731,

Email: takiyama@eng.hokudai.ac.jp 


\section{Abstract}

Magnesium hydride is a promising hydrogen source because of its high mass density of hydrogen, $15.2 \%$, when it is hydrolyzed; $\mathrm{MgH}_{2}+2 \mathrm{H}_{2} \mathrm{O}=\mathrm{Mg}(\mathrm{OH})_{2}+2 \mathrm{H}_{2}+$ $277 \mathrm{~kJ}$. However, a magnesium hydroxide, $\mathrm{Mg}(\mathrm{OH})_{2}$, layer forms rapidly on the surface of the unreacted $\mathrm{MgH}_{2}$ as the $\mathrm{pH}$ increases, hindering further reaction. The purpose of this study is to find acids that could effectively accelerate the reaction by using a chemical equilibrium analysis where the relationships of $\mathrm{pH}$ to concentration of ionized $\mathrm{Mg}$ were calculated. For the best performing acid, the calculated and measured relationships were compared, and the effects of acid concentration on hydrogen release were measured. The analysis revealed that citric acid and ethylenediamine-tetraacetic acid were good buffering agents. The calculated and measured relationships between $\mathrm{pH}$ and concentration of ionized $\mathrm{Mg}$ were in good accord. Hydrogen release improved considerably in a relatively dilute citric acid solution instead of pure distilled water. The maximum amount of hydrogen generated was $1.7 \times 10^{3} \mathrm{~cm}^{3} \cdot \mathrm{g}^{-1}$ at STP after $30 \mathrm{~min}$. We estimated the exact concentration of citric acid solution for complete $\mathrm{MgH}_{2}$ hydrolysis by a chemical equilibrium analysis method.

Keywords; Hydrolysis, Equilibrium analysis, Magnesium hydride, Hydrogen, Buffer 
capacity 


\section{Introduction}

Metal hydrides are a hot topic of discussion among the modern scientific community worldwide because they are used for storage and transport of hydrogen as well as for use in heat pumps as a cold energy supply [1-4] and hydrogen generator [5, 6]. Hydrogen is considered clean energy with a large combustion value that can be used in internal combustion engines or fuel cells. The need for compact, safe, and inexpensive hydrogen sources is a key issue for the development of fuel cells. One of the most attractive metal hydrides for hydrogen generation is magnesium hydride, $\left(\mathrm{MgH}_{2}\right)$ [7-17]. It is an especially promising material owing to its quite high hydrogen capacity of 7.6 mass $\%$ and relatively low production cost. Saita et al., demonstrated that $\mathrm{MgH}_{2}$ can be produced by hydriding chemical vapor deposition (HCVD) in which the $\mathrm{MgH}_{2}$ absorbs and desorbs as much as 7.6 mass\% hydrogen without any activation treatments [18-20], and clarified that the total exergy loss of metal hydride production process without activation treatment is smaller than conventional process [21]. Hydrogen is generated by $\mathrm{MgH}_{2}$ hydrolysis according to the following reaction:

$$
\begin{aligned}
& \mathrm{MgH}_{2}+2 \mathrm{H}_{2} \mathrm{O} \rightarrow \mathrm{Mg}(\mathrm{OH})_{2}+2 \mathrm{H}_{2} \\
& \Delta \mathrm{H}_{298}^{\mathrm{o}}=-277 \mathrm{~kJ} \\
& \Delta \mathrm{G}^{\mathrm{o}}{ }_{298}=-323 \mathrm{~kJ}
\end{aligned}
$$


In fuel cell applications, if the water produced by the fuel cell is redirected to $\mathrm{MgH}_{2}$ hydrolysis, the density of hydrogen increases to 15.2 mass\%. Moreover, this reaction has the advantage that the residual magnesium hydroxide is environmentally friendly. However, the hydrolysis of $\mathrm{MgH}_{2}$ is rapidly hindered by the formation of a passive $\mathrm{Mg}(\mathrm{OH})_{2}$ layer on top of the reactive material as the $\mathrm{pH}$ increases. This is the major problem with generating hydrogen by $\mathrm{MgH}_{2}$ hydrolysis. Acids, with or without the use of catalysts, can suppress the formation of $\mathrm{Mg}(\mathrm{OH})_{2}$ by decreasing the $\mathrm{pH}[7,8,15]$. For example, the kinetics of $\mathrm{MgH}_{2}$ and $\mathrm{Mg}$ hydrolysis were determined by using weak acids or sodium chloride solutions with platinum catalysts [8]. Several studies have used metallic powders with high chemical activity via a ball-milling method [7, 9-16]. However, acids in general are detrimental to equipment and are potential hazards for users, and the price of using catalysts may make their widespread use impractical. In addition, the preparation of ball-milled powders typically requires a large energy input.

The purpose of this study was to use chemical equilibrium analysis to find an effective acid to accelerate the hydrolysis reaction. The main calculation was the effect of the weak-acid on the concentration of ionized $\mathrm{Mg}$ after hydrolysis of $\mathrm{MgH}_{2}$ at room temperature. Thus, we found an effective weak acid for $\mathrm{MgH}_{2}$ hydrolysis at room temperature without catalysts or ball-milling. Additionally, two experiments were 
implemented based on the analysis. In the first experiment, the relationship between the $\mathrm{pH}$ and the concentration of ionized $\mathrm{Mg}$ was investigated. In the second experiment, the effects of weak-acid concentration on hydrogen generation were investigated. 


\section{Equilibrium Analysis}

Equation (1) can be divided into the following equations:

$$
\begin{aligned}
& \mathrm{MgH}_{2}+2 \mathrm{H}_{2} \mathrm{O}=\mathrm{Mg}^{2+}+2 \mathrm{OH}^{-}+2 \mathrm{H}_{2}+279 \mathrm{~kJ} \\
& \mathrm{Mg}^{2+}+2 \mathrm{OH}^{-}=\mathrm{Mg}(\mathrm{OH})_{2}-1 \mathrm{~kJ}
\end{aligned}
$$

When $\mathrm{MgH}_{2}$ is hydrolyzed, the $\mathrm{pH}$ increases with the release of $\mathrm{OH}^{-}$. As a result, $\mathrm{Mg}(\mathrm{OH})_{2}$ is generated on the surface of $\mathrm{MgH}_{2}$, because of the high local concentration of magnesium. In equation (2), the $\mathrm{pH}$ change is calculated as follows. Ion balance before the hydrolysis of $\mathrm{MgH}_{2}$ is expressed by the following equation:

$$
\left[\mathrm{H}^{+}\right]_{\mathrm{b}}=\left[\mathrm{OH}^{-}\right]_{\mathrm{b}}+\left[\mathrm{HCO}_{3}^{-}\right]_{\mathrm{b}}+2\left[\mathrm{CO}_{3}{ }^{2-}\right]_{\mathrm{b}}
$$

The subscript $\mathrm{b}$ indicates concentrations before hydrolysis of $\mathrm{MgH}_{2}$, and the carbonate ions are derived from $\mathrm{CO}_{2}$ in the air. Table 1 gives the reaction equations and their equilibrium constants at a temperature of $298 \mathrm{~K}$.

By equation (4) and the equilibrium constants, the $\mathrm{pH}$ before hydrolysis, $\mathrm{pH}_{\mathrm{b}}=$ $-\log \left[\mathrm{H}^{+}\right]_{\mathrm{b}}$, is determined solely by $p \mathrm{CO}_{2}(0.037 \%)$. The ion balance after hydrolysis is written as equation (5-1).

$$
\left[\mathrm{H}^{+}\right]_{\mathrm{a}}+2\left[\mathrm{Mg}^{2+}\right]_{\mathrm{a}}=\left[\mathrm{OH}^{-}\right]_{\mathrm{a}}+\left[\mathrm{HCO}_{3}{ }^{-}\right]_{\mathrm{a}}+2\left[\mathrm{CO}_{3}{ }^{2-}\right]_{\mathrm{a}}
$$

The subscript a denotes concentrations after hydrolysis of $\mathrm{MgH}_{2}$. Manipulating equation (5-1), we show that the concentration of magnesium ions after hydrolysis of $\mathrm{MgH}_{2}$ is 
given by the following equation:

$$
\left[\mathrm{Mg}^{2+}\right]_{\mathrm{a}}=\left(-\left[\mathrm{H}^{+}\right]_{\mathrm{a}}+\left[\mathrm{OH}^{-}\right]_{\mathrm{a}}+\left[\mathrm{HCO}_{3}{ }^{-}\right]_{\mathrm{a}}+2\left[\mathrm{CO}_{3}{ }^{2-}\right]_{\mathrm{a}}\right) / 2
$$

Substituting the constants into equation 5-2 allows the concentration of magnesium to be calculated by determining the $\mathrm{pH}$ after the hydrolysis. In this analysis, $\left[\mathrm{Mg}^{2+}\right]_{\mathrm{a}}$ was calculated in $\mathrm{pH}$ intervals of 0.1 . Figure 1 shows the relationship between $\left[\mathrm{Mg}^{2+}\right]_{\mathrm{a}}$ and $\mathrm{pH}$ after the hydrolysis of $\mathrm{MgH}_{2}$ and the solubility curve of $\mathrm{Mg}(\mathrm{OH})_{2}$ at $25^{\circ} \mathrm{C}$. When $\left[\mathrm{Mg}^{2+}\right]_{\mathrm{a}}$ is high, the $\mathrm{pH}$ after the hydrolysis is likewise high. When the $\left[\mathrm{Mg}^{2+}\right]_{\mathrm{a}}$ reaches 7 $\mathrm{mmol} \cdot \mathrm{dm}^{-3}$, the $\left[\mathrm{Mg}^{2+}\right]_{\mathrm{a}}$ curve crosses the solubility curve of $\mathrm{Mg}(\mathrm{OH})_{2}$. This calculation suggested that beyond $7 \mathrm{mmol} \cdot \mathrm{dm}^{-3}$, further dissolution of $\mathrm{MgH}_{2}$ was hindered by the deposition of $\mathrm{Mg}(\mathrm{OH})_{2}$ on its surface.

Figure 2 presents several methods to promote $\mathrm{MgH}_{2}$ hydrolysis. The $\mathrm{Mg}(\mathrm{OH})_{2}$ layer can be cracked, or fine $\mathrm{MgH}_{2}$ particles with greater surface area can be used. Heating the solution would be expected to increase the rate constant of the $\mathrm{MgH}_{2}$ hydrolysis. In addition, acetic acid as a buffer, citric acid as a chelator, or zeolite as an ion-exchanger are considered promising additives to accelerate $\mathrm{MgH}_{2}$ hydrolysis by preventing $\mathrm{Mg}(\mathrm{OH})_{2}$ formation. In this analysis, several acids in a range of concentrations were evaluated to buffer the solution during the hydrolysis.

The buffer capacities of the acids were evaluated according to the example 
below for citric acid. Ion balance equations for before and after the hydrolysis are shown as equations (6) and (7-1) respectively.

$$
\begin{aligned}
{\left[\mathrm{H}^{+}\right]_{\mathrm{b}}=\left[\mathrm{OH}^{-}\right]_{\mathrm{b}}+[} & \left.\mathrm{HCO}_{3}{ }^{-}\right]_{\mathrm{b}}+2\left[\mathrm{CO}_{3}{ }^{2-}\right]_{\mathrm{b}} \\
& +\left[\mathrm{H}_{2} \mathrm{Cit}^{-}\right]_{\mathrm{b}}+2\left[\mathrm{HCit}^{2-}\right]_{\mathrm{b}}+\left[3 \mathrm{Cit}^{3-}\right] \\
{\left[\mathrm{H}^{+}\right]_{\mathrm{a}}+2\left[\mathrm{Mg}^{2+}\right]_{\mathrm{a}}=} & {\left[\mathrm{OH}^{-}\right]_{\mathrm{a}}+\left[\mathrm{HCO}_{3}{ }^{-}\right]_{\mathrm{a}}+2\left[\mathrm{CO}_{3}{ }^{2-}\right]_{\mathrm{a}} } \\
& +\left[\mathrm{H}_{2} \mathrm{Cit}^{-}\right]_{\mathrm{a}}+2\left[\mathrm{HCit}^{2-}\right]_{\mathrm{a}}+3\left[\mathrm{Cit}^{3-}\right]_{\mathrm{a}}
\end{aligned}
$$

Here, Cit refers to $\mathrm{C}_{6} \mathrm{H}_{5} \mathrm{O}_{7}$. Equations for the dissociation of citric acid are given below.

$$
\begin{aligned}
& \mathrm{H}_{3} \mathrm{Cit}=\mathrm{H}^{+}+\mathrm{H}_{2} \mathrm{Cit}^{-} \\
& \mathrm{H}_{2} \mathrm{Cit}^{-}=\mathrm{H}^{+}+\mathrm{HCit}^{2-} \\
& \mathrm{HCit}^{2-}=\mathrm{H}^{+}+\mathrm{Cit}^{3-}
\end{aligned}
$$

Finally, the material balance of citric acid is represented by the following equation.

$$
\text { Total Cit }\left(\mathrm{mol} \cdot \mathrm{dm}^{-3}\right)=\left[\mathrm{H}_{3} \mathrm{Cit}\right]+\left[\mathrm{H}_{2} \mathrm{Cit}^{-}\right]+\left[\mathrm{HCit}^{2-}\right]+\left[\mathrm{Cit}^{3-}\right]
$$

The buffer capacities of many different acids were calculated according to the two equations of ion and material balance (6 and 7-1). Figure 3 shows the effect of acid on the $\mathrm{pH}$ buffer capacity at $1 \mathrm{~mol} \cdot \mathrm{dm}^{-3}$ on the rate of $\mathrm{MgH}_{2}$ hydrolysis. The magnesium concentration at the intersection of the buffer capacity and solubility curves indicated the dissolution ratio of $\mathrm{MgH}_{2}$ before $\mathrm{Mg}(\mathrm{OH})_{2}$ forms. Citric acid and ethylenediamine-tetraacetic acid (EDTA) have $\left[\mathrm{Mg}^{2+}\right]_{\mathrm{a}}$ curves that intersected the 
solubility curve of $\mathrm{Mg}(\mathrm{OH})_{2}$ at much higher concentrations than the other acids. This result indicates that citric acid and EDTA have good buffer capacities and thus accelerate $\mathrm{MgH}_{2}$ hydrolysis. Additionally, citric acid and EDTA could chelate metal ions. From these results, citric acid was selected as a buffering agent to accelerate $\mathrm{MgH}_{2}$ hydrolysis in this work.

When $\mathrm{MgH}_{2}$ is hydrolyzed in a citric acid solution, magnesium citrate ions are generated. As a result, the magnesium citrate ions needed to be taken into consideration in the equations of ion and material balance. The two modified equations are given as (7-2) and (11-2) respectively.

$$
\begin{aligned}
{\left[\mathrm{H}^{+}\right]_{\mathrm{a}}+2\left[\mathrm{Mg}^{2+}\right]_{\mathrm{a}}=\left[\mathrm{OH}^{-}\right]_{\mathrm{a}}+\left[\mathrm{HCO}_{3}{ }^{-}\right]_{\mathrm{a}}+2\left[\mathrm{CO}_{3}{ }^{2-}\right]_{\mathrm{a}} } \\
+\left[\mathrm{H}_{2} \mathrm{Cit}^{-}\right]_{\mathrm{a}}+2\left[\mathrm{HCit}^{2-}\right]_{\mathrm{a}}+3\left[\mathrm{Cit}^{3-}\right]_{\mathrm{a}}+\left[\mathrm{MgCit}{ }^{-}\right]
\end{aligned}
$$

Total Cit $\left(\mathrm{mol} \cdot \mathrm{dm}^{-3}\right)$

$$
=\left[\mathrm{H}_{3} \mathrm{Cit}\right]+\left[\mathrm{H}_{2} \mathrm{Cit}^{-}\right]+\left[\mathrm{HCit}^{2-}\right]+\left[\mathrm{Cit}^{3-}\right]+\left[\mathrm{MgCit}^{-}\right]
$$

According to these equations, the concentrations of magnesium ions and magnesium citrate ions were calculated by determining the $\mathrm{pH}$ after hydrolysis and applying them to the above equations. Figure 4 shows the calculated relationships among $\left[\mathrm{Mg}^{2+}\right]_{\mathrm{a}}$, $\left[\mathrm{MgCit}^{-}\right]_{\mathrm{a}}$, and $\mathrm{pH}_{\mathrm{a}}$ when $\mathrm{MgH}_{2}$ is hydrolyzed in citric acid solutions of $0,0.01,0.02$, 0.05 , and $0.1 \mathrm{~mol} \cdot \mathrm{dm}^{-3}$. The sum of $\left[\mathrm{Mg}^{2+}\right]_{\mathrm{a}}$ and $\left[\mathrm{MgCit}^{-}\right]_{\mathrm{a}}$ gives the total amount of 
$\mathrm{MgH}_{2}$ that has dissolved and depends on a value of $\left[\mathrm{Mg}^{2+}\right]$. Then, the maximum amount of $\mathrm{MgH}_{2}$ dissolution depends on the maximum value of $\left[\mathrm{Mg}^{2+}\right]_{\mathrm{a}}$, which is the intersection of the $\left[\mathrm{Mg}^{2+}\right]_{\mathrm{a}}$ curve and the solubility curve of $\mathrm{Mg}(\mathrm{OH})_{2}$. In other words, a higher intersection means a larger amount of $\mathrm{MgH}_{2}$ will dissolve. In Fig. 4, the intersection of the $\left[\mathrm{Mg}^{2+}\right]_{\mathrm{a}}$ curve and the solubility curve rises with increasing citric acid concentration. The amount of $\mathrm{MgH}_{2}$ that could dissolve in a citric acid solution of 0.1 $\mathrm{mol} \cdot \mathrm{dm}^{-3}$, calculated from the sum of the maximum values of $\left[\mathrm{Mg}^{2+}\right]_{\mathrm{a}}$ and $\left[\mathrm{MgCit}^{-}\right]_{\mathrm{a}}$, was more than 25 times that which could dissolve in only water $\left(0 \mathrm{~mol} \cdot \mathrm{dm}^{3}\right)$. Therefore, instead of plain water, citric acid as a buffering agent should greatly accelerate the hydrolysis of $\mathrm{MgH}_{2}$. 


\section{Experimental}

In the first experiment, the $\mathrm{pH}$ and concentration of ionized $\mathrm{Mg}$ after the hydrolysis reaction was investigated. $\mathrm{MgH}_{2}$ was formed into particles by gas-solid reaction (GSR), $99.9 \%$ pure by mass (Biocoke Lab. Co., Pty.), with an average particle size of $60 \mu \mathrm{m}$. Ten $\mathrm{MgH}_{2}$ samples were prepared with different masses; from $0.020 \mathrm{~g}$ to $0.20 \mathrm{~g}$ in intervals of $0.020 \mathrm{~g}$. The samples were soaked in $100 \mathrm{~cm}^{3}$ of $0.05 \mathrm{~mol} \cdot \mathrm{dm}^{-3}$ citric acid and stirred for $24 \mathrm{~h}$. Then, the $\mathrm{pH}$ and the concentration of ionized $\mathrm{Mg}$ were measured with a pH meter (MP125, Mettler Toledo Co., Ltd.) and inductively-coupled plasma atomic emission spectrometry (ICP-AES, iCAP 6300 DUO, Thermo Electron Co., Ltd.) respectively.

In the second experiment, hydrogen release was investigated. Figure 5 shows the experimental setup for investigating the $\mathrm{MgH}_{2}$ hydrolysis in various concentrations of citric acid. The apparatus consisted of two sections, one for hydrolysis and the other for hydrogen collection. The hydrolysis section consisted of a $500 \mathrm{~cm}^{3}$ reaction flask charged with $0.1 \mathrm{~g}$ of $\mathrm{MgH}_{2}$ powder set in a constant-temperature water bath adjusted to $25^{\circ} \mathrm{C}$ and thermistor thermometers set in the reactor and water bath. In the hydrogen collection section, a $250 \mathrm{~cm}^{3}$ measuring cylinder filled with water was set in a water bath, and the reactor and the measuring cylinder were connected by a teflon tube having 
an inner diameter of $2 \mathrm{~mm}$ and length of $1100 \mathrm{~mm}$. Citric acid solutions of 0.005, 0.01, $0.02,0.05$, and $0.1 \mathrm{~mol} \cdot \mathrm{dm}^{-3}$ were prepared by dissolving the powdered reagent (>99.5 \% by mass, Kishida Chemical Co., Pty.) in distilled water. The citric acid solution and distilled water were preheated to $25^{\circ} \mathrm{C}$ in a constant-temperature bath. At the beginning of the experiment, $100 \mathrm{~cm}^{3}$ of the citric acid solution was added to the reactor. The hydrogen generated during the experiment passed through the teflon tube and was collected by the water substitution method. The amount of hydrogen generated was evaluated from the volume and temperature data. The volume changes were monitored by the naked-eye at intervals of $30 \mathrm{~s}$ from 0 to $5 \mathrm{~min}, 60 \mathrm{~s}$ from 5 to $10 \mathrm{~min}$, and $120 \mathrm{~s}$ from 10 to $30 \mathrm{~min}$. The reaction degree, $f$, was calculated by the following equation:

$$
\text { Reaction degree, } f(\%)=\frac{V_{H_{2}} P M_{M_{g} H_{2}}}{2 \Theta_{M_{g} H_{2}} W_{M_{g} H_{2}} R T} \times 100
$$

Here, $V_{\mathrm{H}_{2}}, P, M_{\mathrm{MgH}_{2}}, \Theta_{\mathrm{MgH}_{2}}, W_{\mathrm{MgH}_{2}}, R$, and $T$ indicate the measured gas volume $\left(\mathrm{m}^{3}\right)$, standard pressure $\left(1.00 \times 10^{5} \mathrm{~Pa}\right)$, molar weight of $\mathrm{MgH}_{2}(\mathrm{~g})$, purity of the $\mathrm{MgH}_{2}$ sample (-), weight of the $\mathrm{MgH}_{2}$ sample $(\mathrm{g})$, gas constant $\left(8.314 \mathrm{~J} \cdot \mathrm{mol}^{-1} \cdot \mathrm{K}^{-1}\right)$, and gas temperature $(\mathrm{K})$, respectively. 


\section{Results and Discussion}

Figure 6 shows the calculated and measured relationships between the $\mathrm{pH}$ and the concentration of ionized $\mathrm{Mg}$ in the $0.05 \mathrm{~mol} \cdot \mathrm{dm}^{-3}$ citric acid solution. The measured and calculated curves for the sum of $\left[\mathrm{Mg}^{2+}\right]$ and $\left[\mathrm{MgCit}^{-}\right]$were very close. The chemical equilibrium analysis was confirmed to be precise.

Figure 7 shows the hydrogen release of the $\mathrm{MgH}_{2}$ hydrolysis in different concentrations of citric acid: 0 (distilled water), $0.01,0.02,0.05$, and $0.1 \mathrm{~mol} \cdot \mathrm{dm}^{-3}$. After 30 min in distilled water, the reaction progress was limited to only $13 \%$ because the passive $\mathrm{Mg}(\mathrm{OH})_{2}$ layer formed on the surface of the unreacted $\mathrm{MgH}_{2}$, as expected. In contrast, with citric acid, the hydrogen release improved considerably. Both the rate and degree of hydrogen evolution increased with higher concentrations of citric acid. With the low concentration $\left(0.01 \mathrm{~mol} \cdot \mathrm{dm}^{-3}\right)$, the reaction proceeded to $40 \%$ after $30 \mathrm{~min}$. The reaction in $0.1 \mathrm{~mol} \cdot \mathrm{dm}^{-3}$ citric acid went to $99 \%$ of completion after $30 \mathrm{~min}, 7.7$ times as far as in distilled water. During the experiment, the solution temperature remains constant at $298 \mathrm{~K}$ regardless of the citric acid concentration.

Comparing the hydrogen release (Fig. 7) with the calculated $\mathrm{pH}$ and concentration of ionized $\mathrm{Mg}$ (Fig. 4) showed that the hydrogen release reflected the results of the calculated $\mathrm{pH}$ and concentration of ionized $\mathrm{Mg}$. The second vertical axis 
of Fig. 4 refers to the amount of $\mathrm{MgH}_{2}$ that should dissolve per $100 \mathrm{~cm}^{3}$ of solution. This makes the intersection of $0.1 \mathrm{~mol} \cdot \mathrm{dm}^{-3}$ and the curve of the calculated sum of $\mathrm{Mg}^{2+}$ and $\mathrm{MgCit}^{-}$very important because the ratio between $\mathrm{MgH}_{2}$ and citric acid concentration was the same as that seen in the above experimental conditions. With citric acid concentrations of 0.05 and $0.1 \mathrm{~mol} \cdot \mathrm{dm}^{-3}$, the curves intersected in the area where $\mathrm{Mg}^{2+}$ is stable; thus, a $\mathrm{Mg}(\mathrm{OH})_{2}$ layer should not have formed and the hydrolysis reaction should have proceeded unhindered. In the other cases, there are no intersections; therefore, the $\mathrm{Mg}(\mathrm{OH})_{2}$ layer should form to suppress the hydrolysis. The experimental results were consistent with the calculations as 0.05 and $0.1 \mathrm{~mol} \cdot \mathrm{dm}^{-3}$ citric acid solutions achieved nearly $100 \%$ reaction degree, whereas in the $0,0.01$, and $0.02 \mathrm{~mol} \cdot \mathrm{dm}^{-3}$ citric acid solutions, the reactions stalled out before completion.

These results showed that calculations corresponded closely with the measured results. By this chemical equilibrium analysis method, we can estimate that the exact concentration of citric acid solution necessary for $\mathrm{MgH}_{2}$ hydrolysis. This method will make $\mathrm{MgH}_{2}$ much more attractive as a hydrogen source. 


\section{Conclusions}

A chemical equilibrium analysis was carried out on the formation of $\mathrm{Mg}(\mathrm{OH})_{2}$ during $\mathrm{MgH}_{2}$ hydrolysis with various weak acids, and the effects of the selected acid at various concentrations on hydrogen generation were evaluated experimentally. The three main results are shown below:

1) Citric acid and ethylenediamine-tetraacetic acid have good capacity as $\mathrm{pH}$ buffering agents for accelerating the hydrolysis reaction of $\mathrm{MgH}_{2}$ at room temperature than tartaric, phosphoric, formic, phthalic, acetic, oxalic, and benzoic acids.

2) The hydrogen release was considerably improved by using a low concentration of citric acid solution instead of only distilled water.

3) The calculated relationships between $\mathrm{pH}$ and the concentration of ionized $\mathrm{Mg}$ by the chemical equilibrium analysis corresponded well with the measured results. The exact concentration of citric acid necessary for complete $\mathrm{MgH}_{2}$ hydrolysis can be easily estimated.

$\mathrm{MgH}_{2}$ is a promising hydrogen generator for fuel cells and other energy storage systems. A citric acid solution effectively promotes $\mathrm{MgH}_{2}$ hydrolysis at room temperature without catalysts or ball-milling. 


\section{References}

[1] Nishizaki T, Miyamoto K, Yoshida K. Coefficients of performance of hydride heat pumps. J Less Common Met 1983;89:559-66.

[2] Yanoma A, Yoneta M, Nitta T, Okuda K. The performance of a large scale metal hydride heat pump. JSME International Journal 1988;31:741-7.

[3] Willers E, Groll M. Evaluation of metal hydride machines for heat pumping and cooling applications. Int J of Refrig 1999;22:47-58.

[4] Fedorov EM, Shanin YI, Izhvanov LA. Simulation of hydride heat pump operation. Int J Hydrogen Energy 1999;24:1027-32.

[5] Kong VCY, Foulkes FR, Kirk DW, Hinatsu JT. Development of hydrogen storage for fuel cellgenerators. i: Hydrogen generation using hydrolysishydrides. Int J Hydrogen Energy 1999;24:665-75.

[6] Rangel CM, Fernandes VR, Slavkov Y, Bozukov L. Novel hydrogen generator/storage based on metal hydrides. Int J Hydrogen Energy 2009;34:4587-91.

[7] Huot J, Liang G, Schulz R. Magnesium-based nanocomposites chemical hydrides. J Alloys Compd 2003;353:L12-L5. 
[8] Kojima Y, Suzuki KI, Kawai Y. Hydrogen generation by hydrolysis reaction of magnesium hydride. J Mater Sci 2004;39:2227-9.

[9] Tessier JP, Palau P, Huot J, Schulz R, Guay D. Hydrogen production and crystal structure of ball-milled $\mathrm{MgH}_{2}-\mathrm{Ca}$ and $\mathrm{MgH}_{2}-\mathrm{CaH}_{2}$ mixtures. J Alloys Compd 2004;376:180-5.

[10] Varin RA, Li S, Calka A. Environmental degradation by hydrolysis of nanostructured $\beta-\mathrm{MgH}_{2}$ hydride synthesized by controlled reactive mechanical milling (CRMM) of Mg. J Alloys Compd 2004;376:222-31.

[11] Grosjean MH, Zidoune M, Roué L. Hydrogen production from highly corroding Mg-based materials elaborated by ball milling. J Alloys Compd 2005;404-406:712-5.

[12] Grosjean MH, Zidoune M, Roué L, Huot JY. Hydrogen production via hydrolysis reaction from ball-milled Mg-based materials. Int J Hydrogen Energy 2006;31:109-19.

[13] Grosjean M-H, Roué L. Hydrolysis of $\mathrm{Mg}$-salt and $\mathrm{MgH}_{2}-$ salt mixtures prepared by ball milling for hydrogen production. J Alloys Compounds 2006;416:296-302.

[14] Lukashev R, Yakovleva N, Klyamkin S, Tarasov B. Effect of mechanical activation on the reaction of magnesium hydride with water. Russ J Inorg Chem 2008;53:343-9. 
[15] Makhaev V, Petrova L, Tarasov B. Hydrolysis of magnesium hydride in the presence of ammonium salts. Russ J Inorg Chem 2008;53:858-60.

[16] Fan M-Q, Xu F, Sun L-X, Zhao J-N, Jiang T, Li W-X. Hydrolysis of ball milling $\mathrm{Al}-\mathrm{Bi}-\mathrm{hydride}$ and $\mathrm{Al}-\mathrm{Bi}-$ salt mixture for hydrogen generation. $\mathrm{J}$ Alloys Compd 2008;460:125-9.

[17] Hiroi S, Hosokai S, Akiyama T. Ultrasonic irradiation on hydrolysis of magnesium hydride to enhance hydrogen generation. Int J Hydrogen Energy 2011;36:1442-7.

[18] Saita I, Toshima T, Tanda S, T A. Hydriding Chemical Vapor Deposition of Metal Hydride Nano-Fibers. Mater Trans 2006;47:931-4.

[19] Saita I, Toshima T, Tanda S, Akiyama T. Hydrogen storage property of $\mathrm{MgH}_{2}$ synthesized by hydriding chemical vapor deposition. J Alloys Compd $2007 ; 446-447: 80-3$.

[20] Zhu C, Hayashi H, Saita I, Akiyama T. Direct synthesis of $\mathrm{MgH}_{2}$ nanofibers at different hydrogen pressures. Int J Hydrogen Energy 2009;34:7283-90. [19] Saita I,

[21] Saita I, Akiyama T. Exergy analysis of hydriding combustion synthesis. J Chem. Eng. Japan 2006;525-530:39-5. 
Table 1 Equations and equilibrium constants

\begin{tabular}{|c|c|}
\hline Equations & $\begin{array}{l}\text { Equilibrium } \\
\text { constant, } \mathrm{K}\end{array}$ \\
\hline$\left[\mathrm{H}_{2} \mathrm{CO}_{3}\right] / p \mathrm{CO}_{2}$ & $3.50 \times 10^{-2}$ \\
\hline$\left[\mathrm{H}^{+}\right]\left[\mathrm{HCO}_{3}^{-}\right] /\left[\mathrm{H}_{2} \mathrm{CO}_{3}\right]$ & $4.31 \times 10^{-7}$ \\
\hline$\left[\mathrm{H}^{+}\right]\left[\mathrm{CO}_{3}{ }^{2-}\right] /\left[\mathrm{HCO}_{3}{ }^{-}\right]$ & $4.68 \times 10^{-11}$ \\
\hline$\left[\mathrm{H}^{+}\right]\left[\mathrm{H}_{2} \mathrm{PO}_{4}^{-}\right] /\left[\mathrm{H}_{3} \mathrm{PO}_{4}\right]$ & $5.90 \times 10^{-3}$ \\
\hline$\left[\mathrm{H}^{+}\right]\left[\mathrm{HPO}_{4}{ }^{2-}\right] /\left[\mathrm{H}_{2} \mathrm{PO}_{4}^{-}\right]$ & $6.22 \times 10^{-8}$ \\
\hline$\left[\mathrm{H}^{+}\right]\left[\mathrm{PO}_{4}^{3-}\right] /\left[\mathrm{HPO}_{4}{ }^{2-}\right]$ & $3.87 \times 10^{-13}$ \\
\hline$\left[\mathrm{H}^{+}\right]\left[\mathrm{CH}_{3} \mathrm{COO}^{-}\right] /\left[\mathrm{CH}_{3} \mathrm{COOH}\right]$ & $1.55 \times 10^{-5}$ \\
\hline$\left[\mathrm{H}^{+}\right]\left[\mathrm{H}_{3} \mathrm{Y}^{-}\right] /\left[\mathrm{H}_{4} \mathrm{Y}^{*}\right]$ & $1.00 \times 10^{-2}$ \\
\hline$\left[\mathrm{H}^{+}\right]\left[\mathrm{H}_{2} \mathrm{Y}^{2-}\right] /\left[\mathrm{H}_{3} \mathrm{Y}^{-}\right]$ & $2.10 \times 10^{-3}$ \\
\hline$\left[\mathrm{H}^{+}\right]\left[\mathrm{HY}^{3-}\right] /\left[\mathrm{H}_{2} \mathrm{Y}^{2-}\right]$ & $6.90 \times 10^{-7}$ \\
\hline$\left[\mathrm{H}^{+}\right]\left[\mathrm{Y}^{4-}\right] /\left[\mathrm{HY}^{3-}\right]$ & $6.00 \times 10^{-11}$ \\
\hline$\left[\mathrm{H}^{+}\right]\left[\mathrm{COOHCOO}^{-}\right] /\left[(\mathrm{COOH})_{2}\right]$ & $5.60 \times 10^{-2}$ \\
\hline$\left[\mathrm{H}^{+}\right]\left[(\mathrm{COO})_{2}^{2-}\right] /\left[\mathrm{COOHCOO}^{-}\right]$ & $5.20 \times 10^{-5}$ \\
\hline$\left[\mathrm{H}^{+}\right]\left[\mathrm{C}_{6} \mathrm{H}_{5} \mathrm{COO}^{-}\right] /\left[\mathrm{C}_{6} \mathrm{H}_{5} \mathrm{COOH}\right]$ & $6.30 \times 10^{-5}$ \\
\hline$\left[\mathrm{H}^{+}\right]\left[\mathrm{H}_{2} \mathrm{Cit}^{-}\right] /\left[\mathrm{H}_{3} \mathrm{Cit}^{* *}\right]$ & $7.40 \times 10^{-4}$ \\
\hline$\left[\mathrm{H}^{+}\right]\left[\mathrm{HCit}^{2-}\right] /\left[\mathrm{H}_{2} \mathrm{Cit}^{-}\right]$ & $1.80 \times 10^{-5}$ \\
\hline$\left[\mathrm{H}^{+}\right]\left[\mathrm{Cit}^{3-}\right] /\left[\mathrm{HCit}^{2-}\right]$ & $4.00 \times 10^{-7}$ \\
\hline
\end{tabular}




\begin{tabular}{cc}
{$\left[\mathrm{H}^{+}\right]\left[\mathrm{HCOO}^{-}\right] /[\mathrm{HCOOH}]$} & $1.70 \times 10^{-4}$ \\
{$\left[\mathrm{H}^{+}\right]\left[\mathrm{C}_{6} \mathrm{H}_{5} \mathrm{O}^{-}\right] /\left[\mathrm{C}_{6} \mathrm{H}_{5} \mathrm{OH}\right]$} & $1.10 \times 10^{-10}$ \\
{$\left[\mathrm{H}^{+}\right]\left[\mathrm{C}_{6} \mathrm{H}_{4} \mathrm{COOH}(\mathrm{COO})^{-}\right] /\left[\mathrm{C}_{6} \mathrm{H}_{4}(\mathrm{COOH})_{2}\right]$} & $1.10 \times 10^{-3}$ \\
{$\left[\mathrm{H}^{+}\right]\left[\mathrm{C}_{6} \mathrm{H}_{4}(\mathrm{COO})_{2}{ }^{2-}\right] /\left[\mathrm{C}_{6} \mathrm{H}_{4} \mathrm{COOH}(\mathrm{COO})^{-}\right]$} & $3.90 \times 10^{-6}$ \\
{$\left[\mathrm{H}^{+}\right]\left[\mathrm{HC}_{4} \mathrm{H}_{4} \mathrm{O}_{6}{ }^{-}\right] /\left[\mathrm{H}_{2} \mathrm{C}_{4} \mathrm{H}_{4} \mathrm{O}_{6}\right]$} & $9.10 \times 10^{-4}$ \\
{$\left[\mathrm{H}^{+}\right]\left[\mathrm{C}_{4} \mathrm{H}_{4} \mathrm{O}_{6}{ }^{2-}\right] /\left[\mathrm{HC}_{4} \mathrm{H}_{4} \mathrm{O}_{6}{ }^{-}\right]$} & $4.30 \times 10^{-5}$ \\
{$\left[\mathrm{Mg}^{2+}\right]\left[\mathrm{OH}^{-}\right]$} & $4.03 \times 10^{-12}$ \\
{$\left[\mathrm{Mg}^{2+}\right]\left[\mathrm{Cit}^{3-}\right] /\left[\mathrm{MgCit}^{-}\right]$} & $2.80 \times 10^{-4}$ \\
{$\left[\mathrm{H}^{+}\right]\left[\mathrm{OH}^{-}\right]$} & $1.01 \times 10^{-14}$ \\
\hline
\end{tabular}

$* \mathrm{H}_{4} \mathrm{Y}: \mathrm{C}_{2} \mathrm{H}_{4}\left[\mathrm{~N}\left(\mathrm{CH}_{2} \mathrm{COOH}\right)_{2}\right]_{2} \quad * * \mathrm{H}_{3} \mathrm{Cit}: \mathrm{H}_{3} \mathrm{C}_{6} \mathrm{H}_{5} \mathrm{O}_{7}$ 


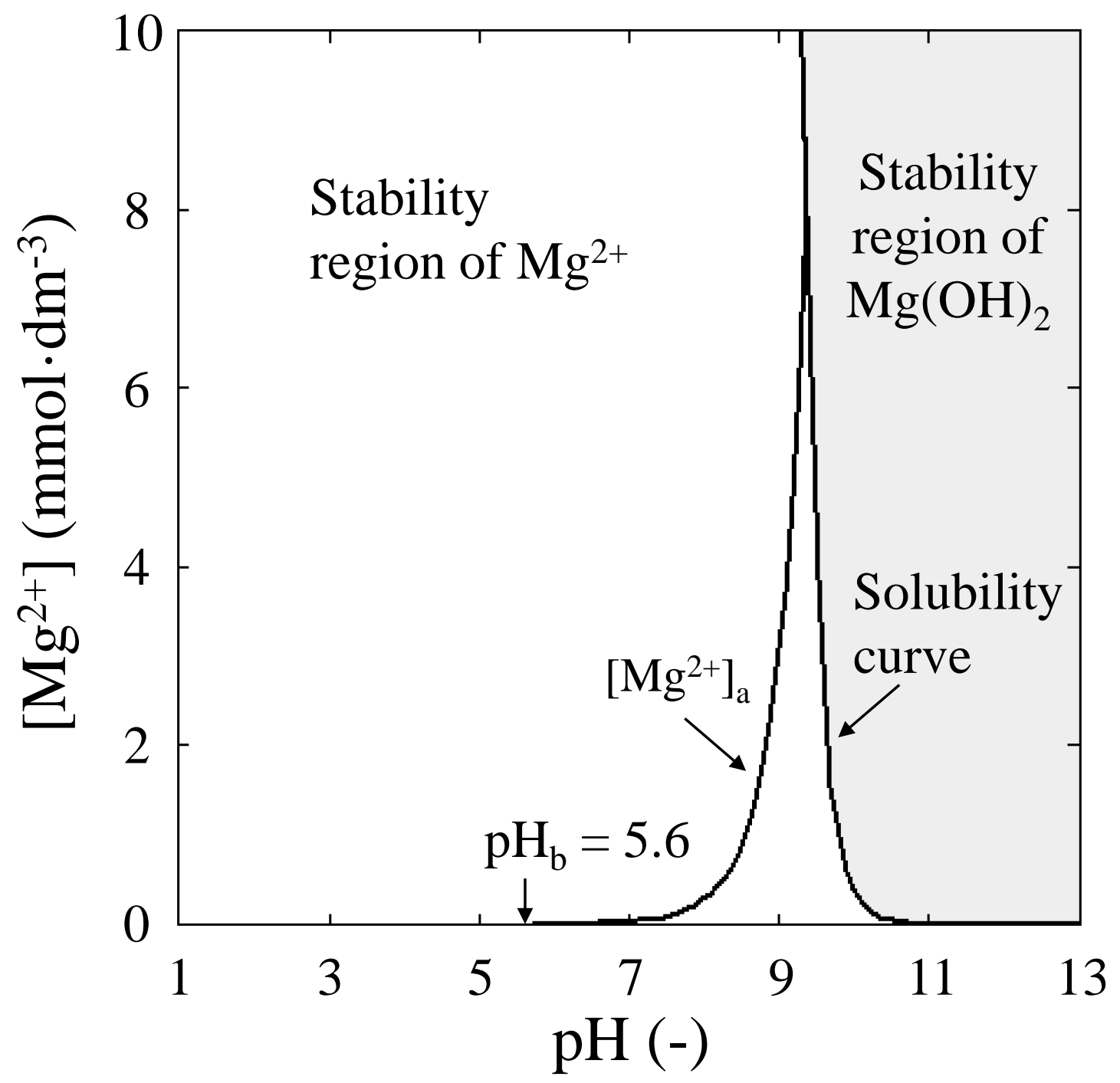

Fig.1 Relationship of magnesium ion and $\mathrm{pH}$ in the solution after hydrolysis of $\mathrm{MgH}_{2}$ with water and the solubility curve of $\mathrm{Mg}(\mathrm{OH})_{2}$ at temperature of $25^{\circ} \mathrm{C}$. Note that the subscripts a and $\mathrm{b}$ indicate the after and before hydrolysis reaction. 


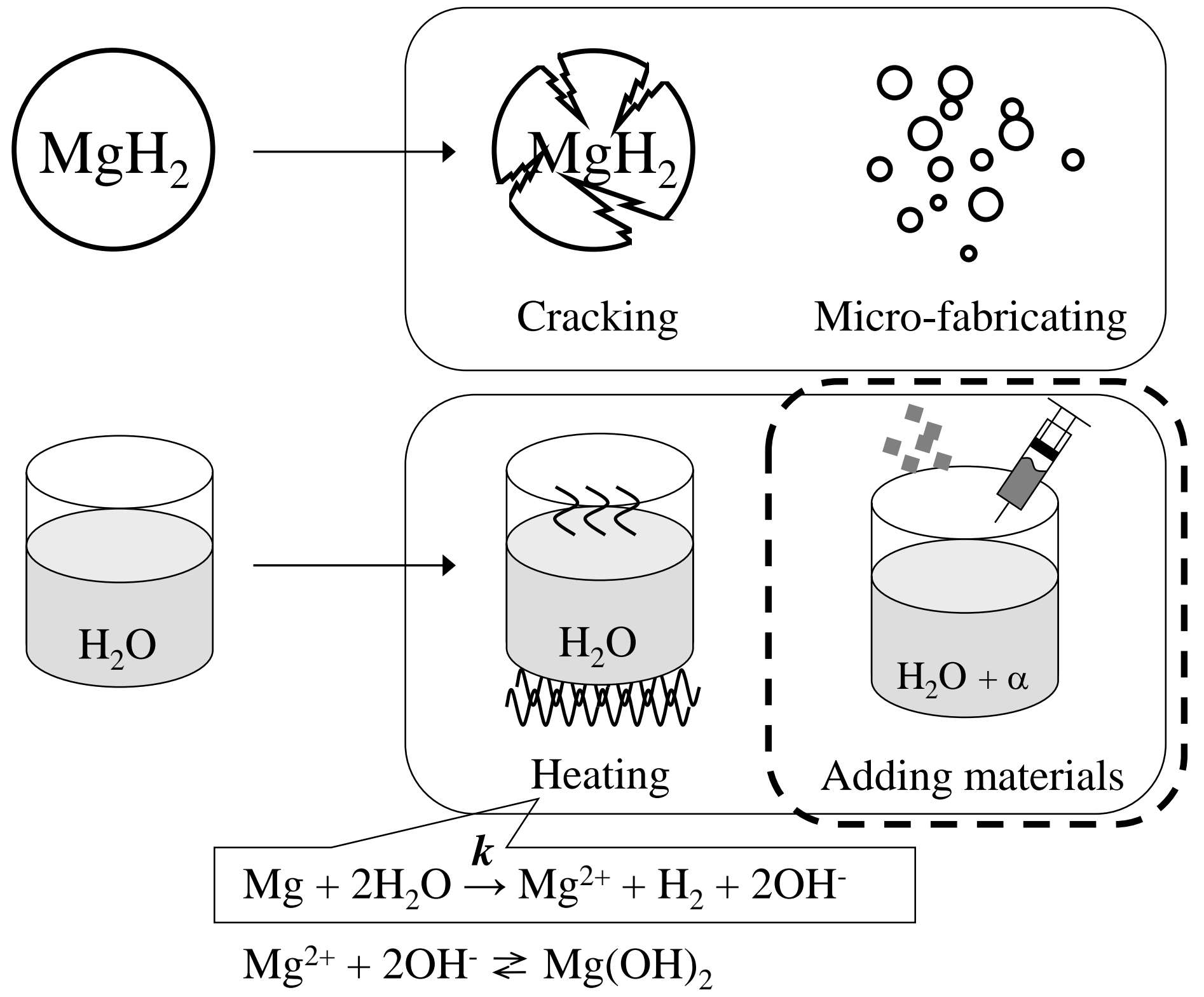

Fig. 2 Several processing for accelerating of $\mathrm{MgH}_{2}$ hydrolysis. 

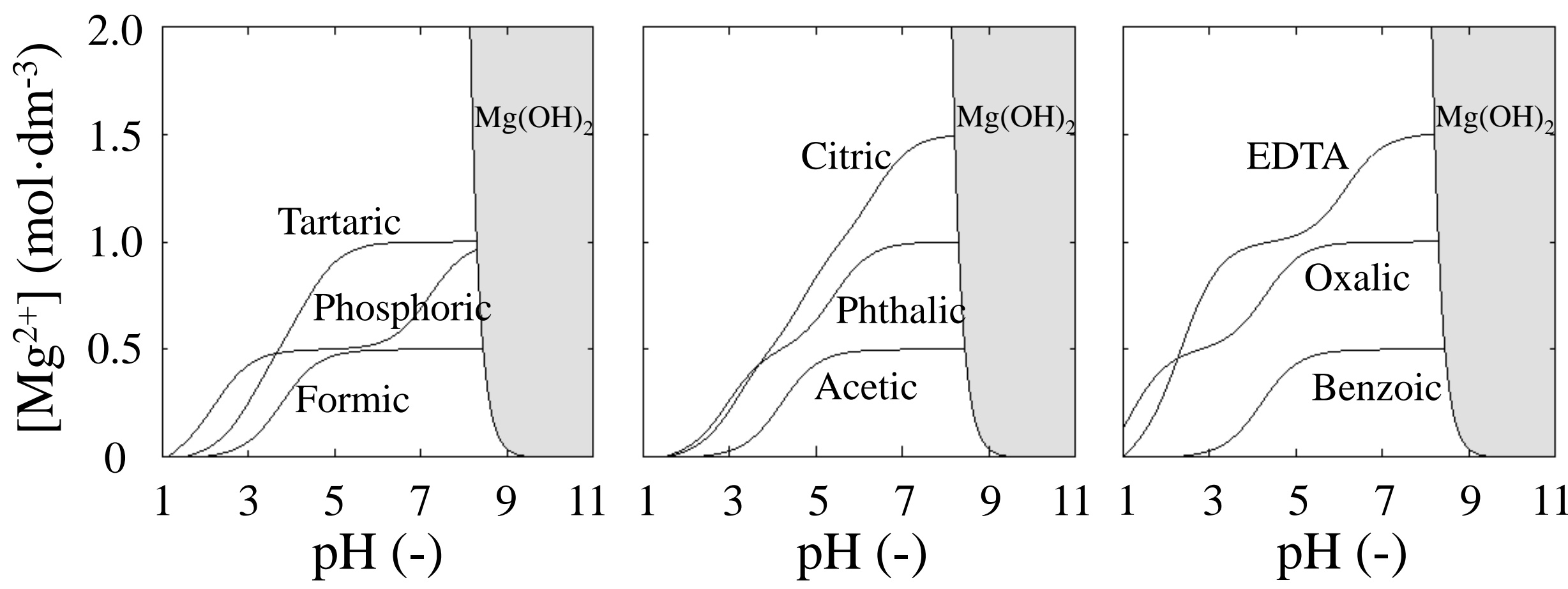

Fig.3 Effect of acid type on buffer capacity of $\mathrm{pH}$ under $\mathrm{MgH}_{2}$ hydrolysis. The concentration of acid is $1.0 \mathrm{~mol} \cdot \mathrm{dm}^{-3}$ and the temperature of the solution is $25^{\circ} \mathrm{C}$. 


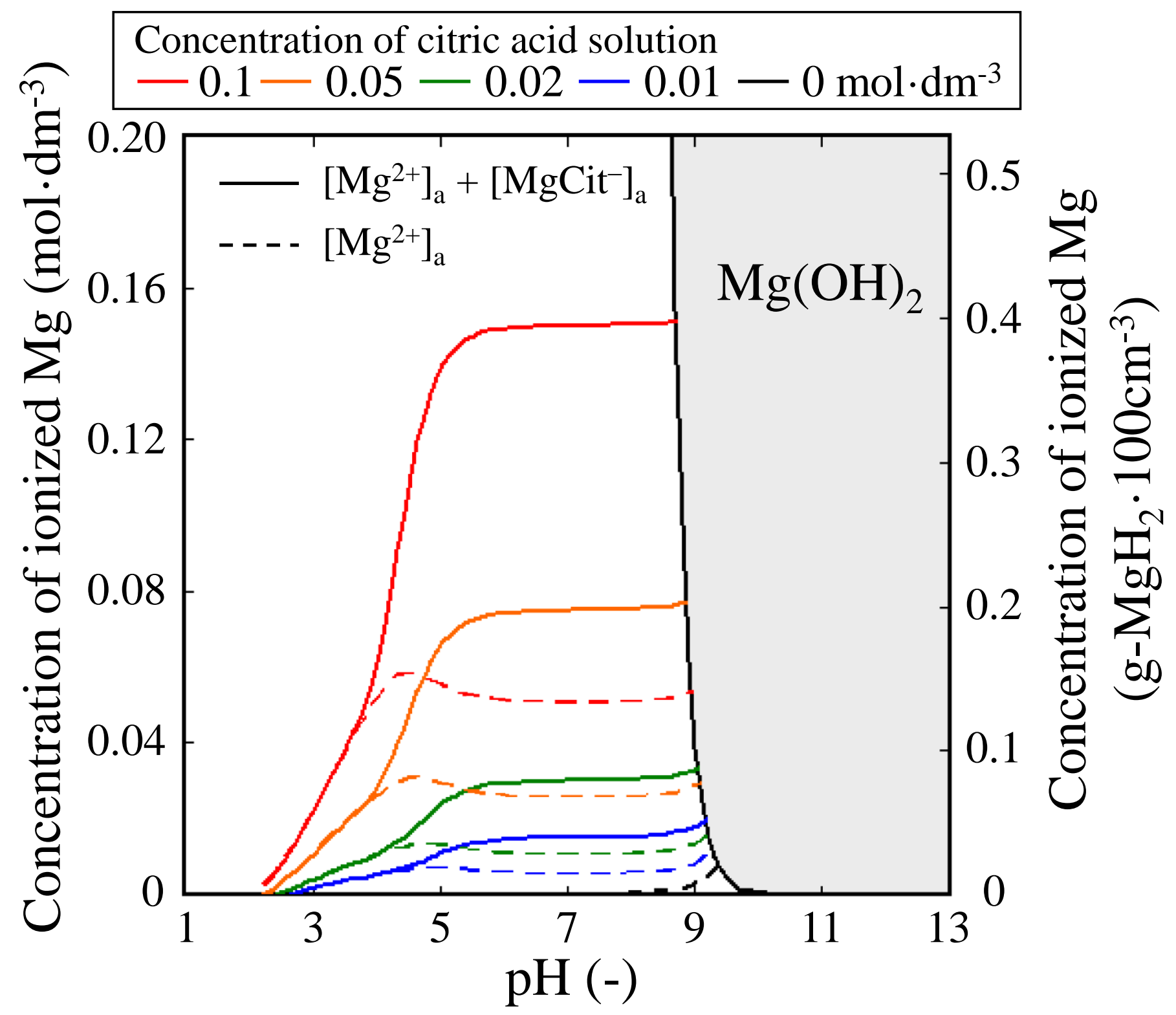

Fig.4 Effect of concentration of citric acid on buffer capacity of $\mathrm{pH}$ under $\mathrm{MgH}_{2}$ hydrolysis in temperature of $25^{\circ} \mathrm{C}$. 


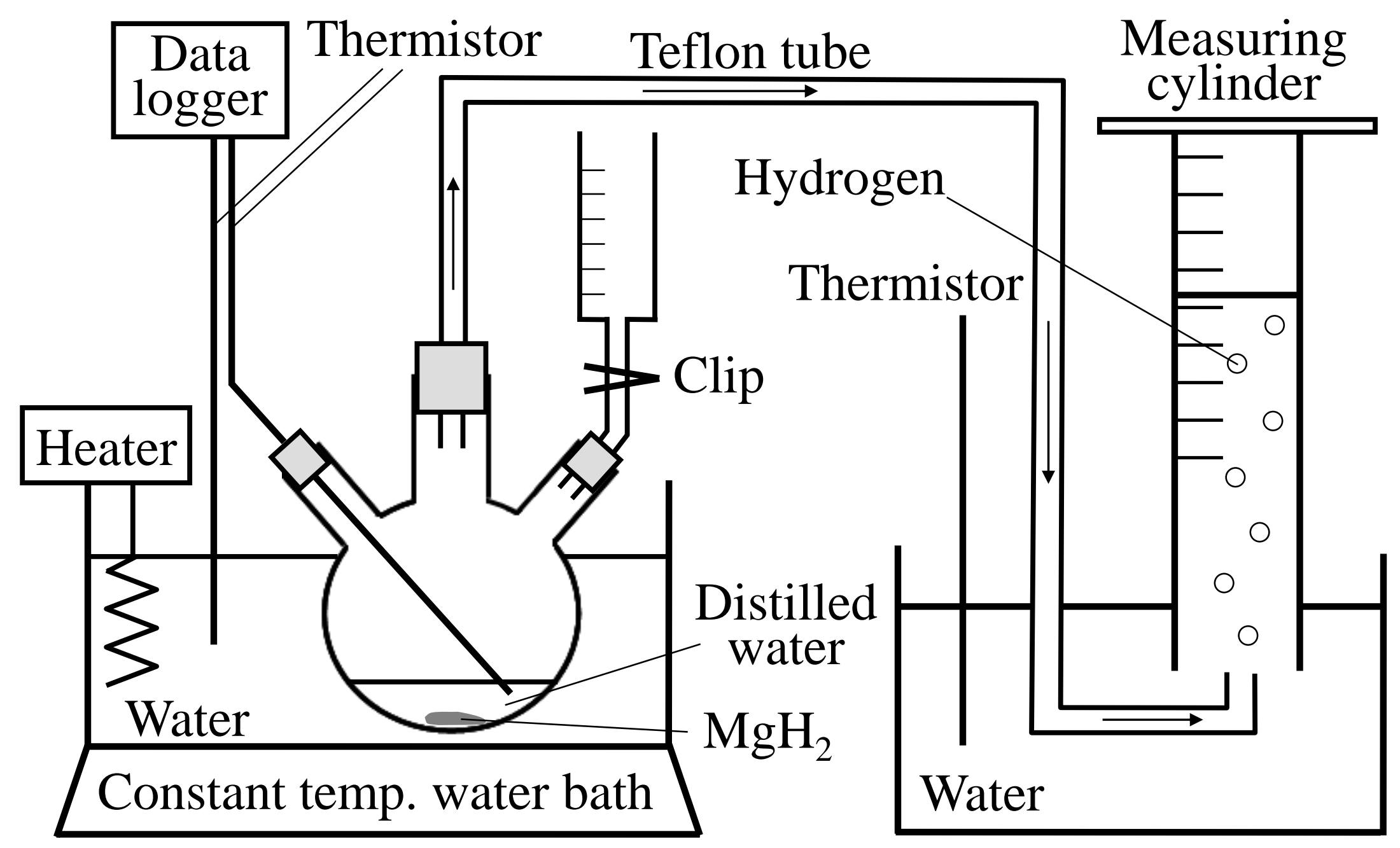

Fig.5 Schematic diagram of the experimental setup for measuring the amount of hydrogen generated from the hydrolysis of $\mathrm{MgH}_{2}$.

$100 \mathrm{~cm}^{3}$ of distilled water or citric acid solution was added to the reactor containing $0.1 \mathrm{~g}$ of $\mathrm{MgH}_{2}$ at $25^{\circ} \mathrm{C}$ and the generated $\mathrm{H}_{2}$ was collected by a water substitution method. 


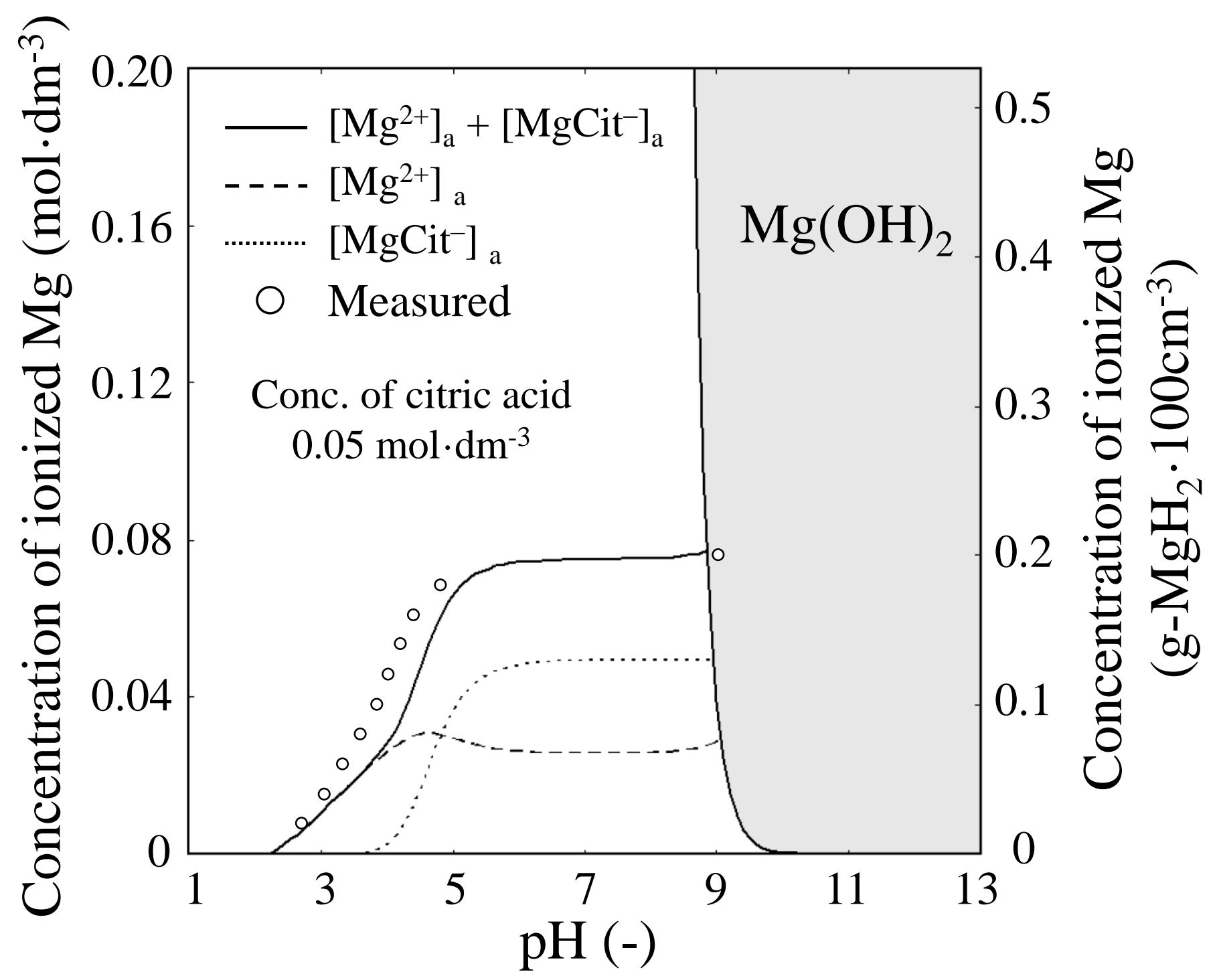

Fig.6 Calculated and measured relationships between $\mathrm{pH}$ and concentration of ionized $\mathrm{Mg}$ under the condition using citric acid solution of $0.05 \mathrm{~mol} \cdot \mathrm{dm}^{-3}$ 


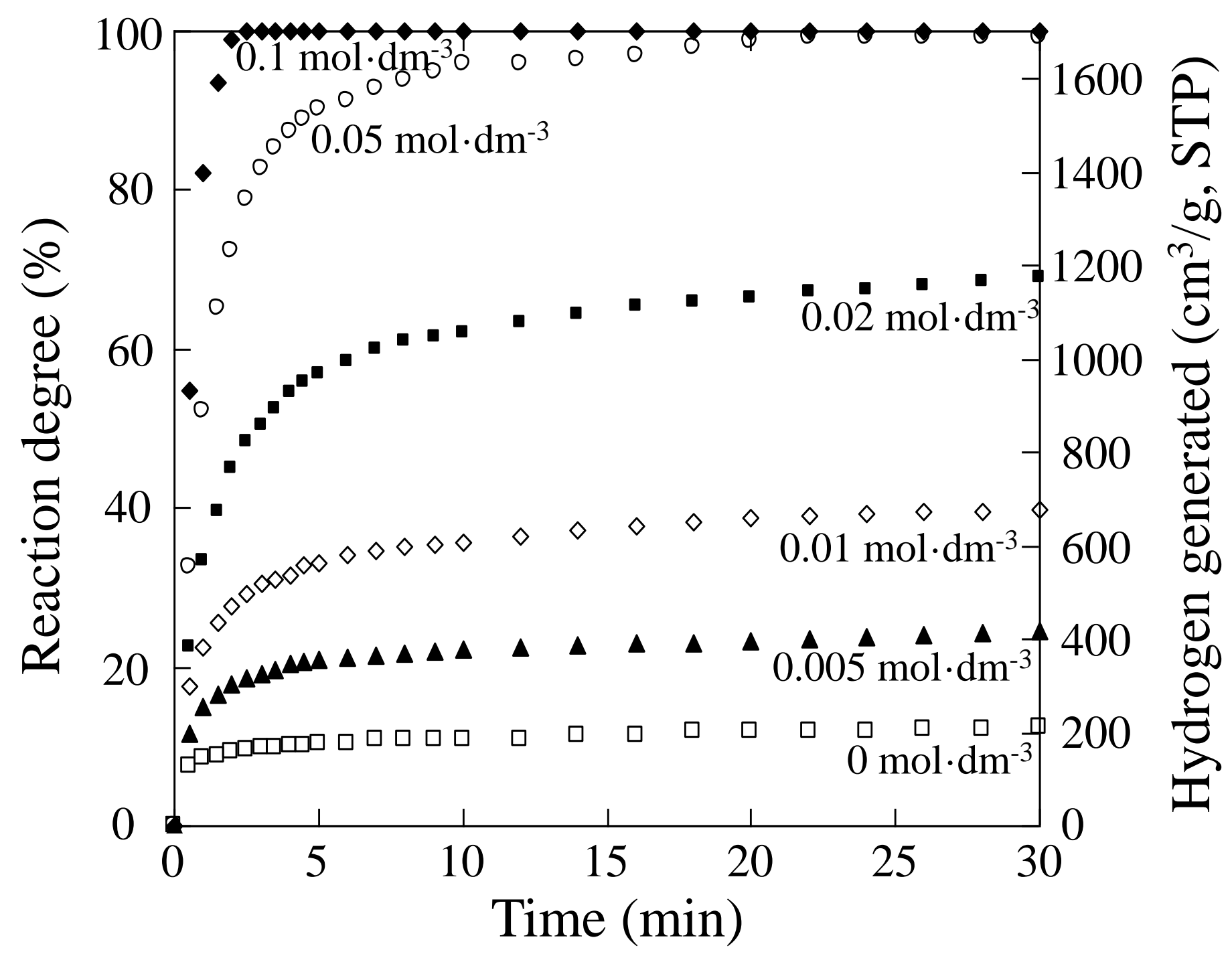

Fig.7 Effect of concentration of citric acid on the hydrogen generation from hydrolysis of $0.1 \mathrm{~g}$ of $\mathrm{MgH}_{2}$ was hydrolyzed with $100 \mathrm{~cm}^{3}$ of distilled water or citric acid solution. 